\title{
ANALISA PERBANDINGAN KONSENTRASI KLOROFIL ANTARA CITRA SATELIT TERRA DAN AQUA/MODIS DITINJAU DARI SUHU PERMUKAAN LAUT DAN MUATAN PADATAN TERSUSPENSI
}

(Studi Kasus : Perairan Selat Madura dan sekitarnya)

\author{
Risdina Trisna Wardani, Bangun Muljo Sukojo \\ Program Studi Teknik Geomatika FTSP-ITS, Kampus ITS Sukolilo, Surabaya, 60111 \\ Email : riezna@geodesy.its.ac.id
}

\begin{abstract}
Abstrak
Penentuan daerah tangkapan ikan memerlukan pengamatan persebaran konsentrasi klorofil di permukaan laut untuk menentukan tempat berkumpulnya ikan. Pada umumnya untuk mengekstrak informasi mengenai persebaran klorofil metode yang banyak digunakan adalah metode penginderaan jauh.

Pemantauan hasil yang terbaik diperlukan dalam melakukan analisa untuk pengamatan daerah tangkapan ikan dari keberadaan klorofil. Analisa tersebut menggunakan citra satelit Terra dan Aqua MODIS. Algoritma menggunakan algoritma Algorithm Theoretical Basic Document Modis (ATBD) 19 Modis dan O'Reilly (1998) untuk menentukan konsentrasi klorofil pada daerah penelitian, dengan waktu penelitian pada musim timur yang dilakukan pada bulan Juli 2011. Daerah penelitian yang digunakan dalam penelitian ini adalah wilayah perairan Selat Madura dan sekitarnya.

Dari hasil pengolahan data dan analisa didapatkan citra yang mempunyai hasil yang baik adalah citra Aqua MODIS, dengan rata-rata klorofil tahun 2011 sebesar 0,01692 mg/m3 dengan nilai SPL dan MPT sebesar 31,5 ${ }^{\circ} \mathrm{C}$ dan 98,87 $\mathrm{mg} / \mathrm{l}$. Uji validasi yang dilakukan bernilai $77,57 \%$, yang menunjukkan klorofil pengolahan citra mempresentasikan kondisi sesungguhnya. Data hasil analisis dapat dijadikan sebagai bahan referensi penelitian selanjutnya.
\end{abstract}

Kata Kunci : Citra, Penginderaan Jauh, Klorofil

\section{PENDAHULUAN}

\section{Latar Belakang}

Selat Madura yang dijadikan sebagai tempat penelitian adalah daerah yang terkena dampak dari semburan lumpur panas Sidoarjo. Daerah tersebut mengakibatkan adanya suatu perubahan persebaran konsentrasi klorofil, diakibatkan adanya material endapan yang dibawa mengalir ke perairan Selat Madura. Hal ini akan mempengaruhi kualitas perairan di Selat Madura dan sekitarnya.

Oleh karena itu, perlu adanya suatu penelitian mengenai perubahan konsentrasi klorofil di Selat Madura dengan menggunakan teknologi penginderaan jauh, yaitu dengan data citra MODIS. Untuk melihat perkembangannya dari tahun ke tahun dapat menggunakan ilmu penginderaan jauh. Penggunaan penginderaan jauh dapat mencakup suatu areal yang luas dalam waktu bersamaan. Penginderaan jauh dapat digunakan untuk mendeteksi sebaran konsentrasi klorofil secara cepat, efektif, efisien dan dapat 68 mencakup wilayah yang lebih luas dibandingkan dengan pengukuran langsung yang membutuhkan biaya serta tenaga yang lebih banyak.

Penelitian ini mencoba menggali potensi dan aplikasi data MODIS untuk mendapatkan parameter oseanografi, khususnya parameter persebaran konsentrasi klorofil. Sensor MODIS yang terpasang pada satelit Terra dan Aqua dapat mengukur hampir semua parameter darat, laut, dan udara sehingga kegunaannya menjadi sangat luas. Mulai dari indeks tumbuhan, kelembaban tanah, kadar aerosol di udara, suhu permukaan laut, dan kandungan klorofil laut.

\section{Rumusan Permasalahan}

Perumusan masalah dalam penelitian ini adalah bagaimana analisa hasil persebaran konsentrasi klorofil di perairan Selat Madura dengan parameter suhu permukaan laut (SPL) dan muatan padatan tersuspensi (MPT) antara citra satelit Aqua dan Terra/MODIS tahun 2009-2011 pada bulan Juli. 


\section{Batasan Masalah/Ruang Lingkup}

Batasan permasalahan dari penelitian tugas akhir ini adalah :

1. Penelitian ini dilakukan di daerah sekitar perairan Selat Madura dan sekitarnya.

2. Data primer yang digunakan adalah data citra satelit Aqua dan Terra/MODIS tahun 20092011 pada bulan Juli.

3. Metode yang digunakan dalam penelitian ini dengan perhitungan klorofil menggunakan algoritma Algorithm Theoretical Basic Document Modis (ATBD) dari Modis dan Algoritma O'Rilley (1998)

4. Hasil penelitian adalah perbandingan persebaran konsentrasi klorofil antara citra satelit Aqua dan Terra MODIS ditinjau dari parameter suhu permukaan laut (SPL) dan muatan padatan tersuspensi (MPT) atau Total Suspended Metter (TSM).

\section{Tujuan}

Tujuan penulisan tugas akhir ini adalah untuk menghasilkan peta konsentrasi klorofil dari hasil pengolahan data citra satelit Aqua dan Terra MODIS, serta mengetahui satelit yang lebih efektif dalam mendeteksi klorofil di perairan Selat Madura dan sekitarnya, pada waktu temporal tertentu di lapangan dengan citra satelit yang digunakan.

\section{Manfaat}

Manfaat yang ingin diperoleh dari penelitian ini adalah memberikan suatu informasi spasial (peta) serta hasil persebaran konsentrasi klorofil dengan menggunakan parameter suhu permukaan laut (SPL) dan Total Suspended Metter (TSM) antara citra satelit Aqua dan Terra MODIS. Hasil analisa selanjutnya dijadikan sebagai bahan referensi penelitian yang terkait dengan bidang kelautan seperti penentuan daerah tangkapan ikan dan konservasi ekosistem.

\section{METODOLOGI PENELITIAN}

\section{Lokasi Penelitian}

Lokasi penelitian ini mengambil daerah studi di perairan Selat Madura dan sekitarnya. Secara geografis terletak pada $5^{\circ} 7^{\prime} 42,49^{\prime \prime}-9^{\circ} 27^{\prime} 36,13^{\prime \prime} \mathrm{LS}$ dan $110^{\circ} 3^{\prime} 40,50^{\prime \prime}-115^{\circ} 49^{\prime} 31,70^{\prime \prime}$ BT dalam penelitian berada pada posisi pada Gambar 1.

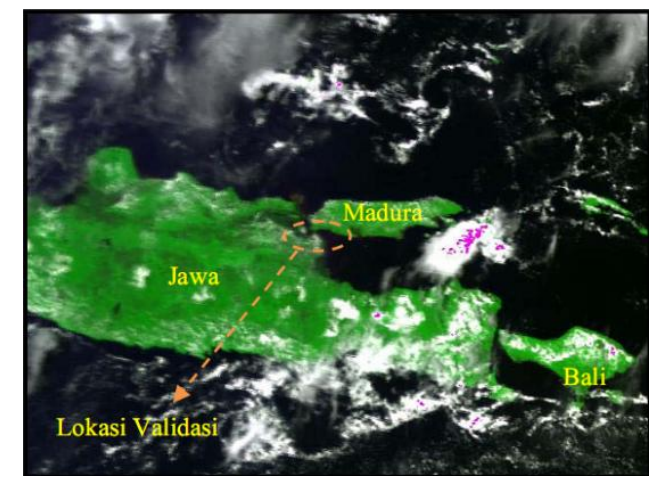

Gambar 1. Lokasi Daerah penelitian

\section{Pengolahan Data}

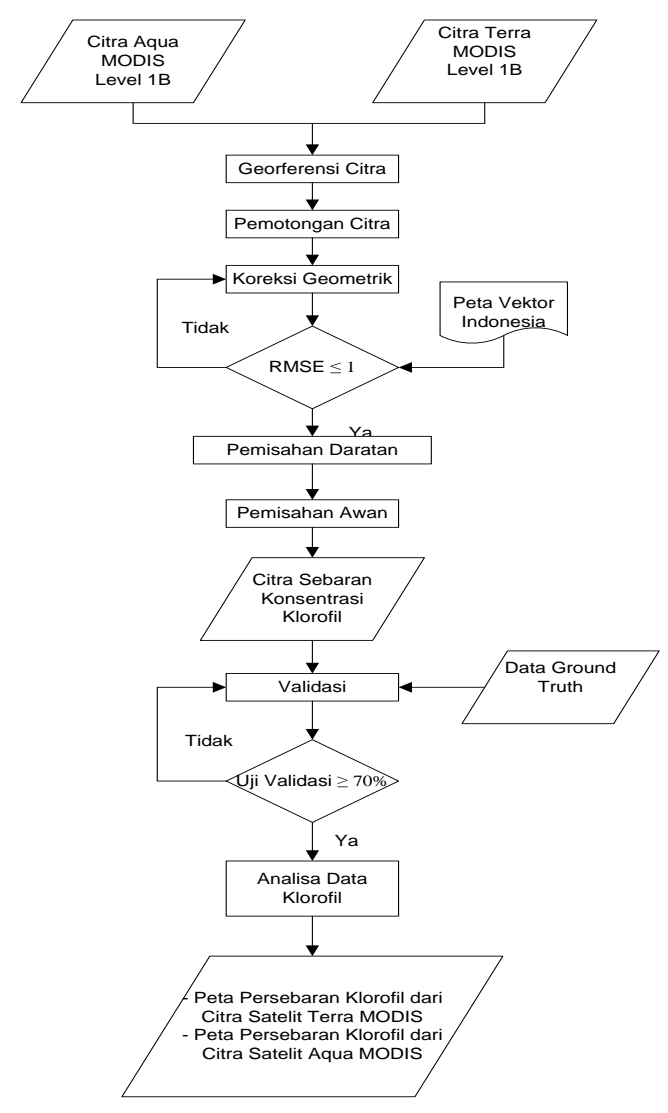

Gambar 2. Diagram Alir Pengolahan Citra

\section{Klorofil}

Klorofil merupakan pigmen penting yang diperlukan fitoplankton_dalam melakukan proses fotosintesis. Fitoplankton berperan sebagai produsen primer dalam rantai kehidupan di laut, sehingga keberadaannya sangat penting sebagai dasar kehidupan di laut. Kesuburan perairan, salah satu indikatornya dinyatakan dalam konsentrasi klorofil. Perairan di daerah tropis 
umunya memiliki konsentrasi klorofil yang rendah karena keterbatasan nutrien dan kuatnya stratifikasi kolom perairan akibat pemanasan permukan perairan yang terjadi hampir sepanjang tahun. Namun berdasarkan pola persebaran konsentrasi klorofil secara musiman maupun secara spasial, di beberapa bagian perairan dijumpai konsentrasi klorofil yang cukup tinggi.

\section{Algoritma MODIS untuk Klorofil \\ Penerapan Algoritma O'Rilley (1998)}

Algoritma yang digunakan dalam pengolahan nilai konsentrasi klorofil adalah pemikiran Rilley. Algoritma ini membandingkan nilai reflektansi pada kanal 9 (438-448 nm) dan kanal 12 (546-556 $\mathrm{nm})$ pada sensor MODIS, dengan persamaan sebagai berikut:

$\log (c \mid r)=0,283-2,753 R+1,457 R^{2}+0,659 R^{3}-$ $1,403 R^{4}$

Clor $=10{ }^{(0,283-2,753 R+1,457 R 2+0,659 R 3-1,403 R 4)}$

Keterangan:

$\mathrm{R}=$ rasio band $9 /$ band 12

\section{Penerapan Algoritma ATBD 19}

Algoritma yang digunakan dalam pengolahan nilai konsentrasi klorofil yang mengacu pada Algorithm Theoretical Basic Document Modis 19 (ATBD 19) dengan persamaan sebagai berikut:

$$
R=\log \left(\frac{\operatorname{Rrs} 488}{\operatorname{Rrs} 551}\right)
$$

Dengan $C$ didefinisikan sebagai nilai kandungan klorofil, Rrs 551 didefinisikan sebagai nilai reflektansi permukaan pada panjang gelombang $551 \mathrm{~nm}$, pada citra satelit MODIS Aqua nilai reflektansi ini diwakili oleh kanal 12, Rrs 488 didefinisikan sebagai nilai reflektansi permukaan pada panjang gelombang $488 \mathrm{~nm}$, pada citra satelit MODIS Aqua nilai reflektansi ini diwakili oleh kanal 10.

\section{HASIL DAN PEMBAHASAN}

\section{Koreksi Geometrik Citra dan SOF}

Hasil koreksi geometrik pada citra Terra dan Aqua MODIS, sebagai berikut:

a. Citra Terra MODIS diperoleh nilai rata-rata $\mathrm{RMS}_{\text {error }}$ sebesar $<0,6$, diantaranya:
- Citra Terra MODIS 2009 hasil koreksi geometrik diperoleh rata-rata nilai $\mathrm{RMS}_{\text {error }}$ sebesar 0,431 piksel,

- Citra Terra MODIS 2010 hasil koreksi geometrik diperoleh rata-rata nilai $\mathrm{RMS}_{\text {error }}$ sebesar 0,735 piksel,

- Citra Terra MODIS 2011 hasil koreksi geometrik diperoleh rata-rata nilai $\mathrm{RMS}_{\text {error }}$ sebesar 0,635 piksel.

b. Citra Aqua MODIS diperoleh nilai rata-rata $\mathrm{RMS}_{\text {error }}$ sebesar $<0.6$, diantaranya:

- Citra Aqua MODIS 2009 hasil koreksi geometrik diperoleh rata-rata nilai $\mathrm{RMS}_{\text {error }}$ sebesar 0,468 piksel,

- Citra Aqua MODIS 2010 hasil koreksi geometrik diperoleh rata-rata nilai $\mathrm{RMS}_{\text {error }}$ sebesar 0,693 piksel,

Citra Aqua MODIS 2011 hasil koreksi geometrik diperoleh rata-rata nilai $\mathrm{RMS}_{\text {error }}$ sebesar 0,622 piksel.

Nilai strength of figure dari titik kontrol registrasi citra untuk setiap citra yang digunakan adalah 0,0012 Dalam hal ini semakin kecil bilangan faktor kekuatan jaringan tersebut di atas, maka akan semakin baik konfigurasi jaringan yang bersangkutan, dan sebaliknya.

Hasil $\mathrm{RMS}_{\text {error }}$ rata-rata citra mempunyai nilai $\mathrm{RMS}_{\text {error }}$ rata-rata kurang dari 1 pixel dan SoF mendekati nol sehingga dianggap memenuhi toleransi yang diberikan (Purwadhi, 2001).

\section{Hasil Peta}

- Peta Persebaran Klorofil 2009 dari Citra Satelit Terra MODIS

- Peta Persebaran Klorofil 2010 dari Citra Satelit Terra MODIS

- Peta Persebaran Klorofil 2011 dari Citra Satelit Terra MODIS

- Peta Persebaran Klorofil 2009 dari Citra Satelit Aqua MODIS

- Peta Persebaran Klorofil 2010 dari Citra Satelit Aqua MODIS

- Peta Persebaran Klorofil 2011 dari Citra Satelit Aqua MODIS 


\section{Analisa Data Lapangan}

Data lapangan tersebut setelah diinputkan pada citra yang terkoreksi geometrik, diperoleh 3 data yang sesuai dengan piksel citra.

Tabel 1. Data Lapangan Klorofil

\begin{tabular}{cc}
\hline Posisi Titik & Nilai Klorofil $(\mathrm{mg} / \mathrm{m3})$ \\
\hline 1 & 0,016678 \\
2 & 0,016452 \\
3 & 0,016201 \\
\hline
\end{tabular}

\section{Hasil Pengolahan Citra}

Nilai klorofil citra diambil 3 data piksel yang disesuaikan dengan data lapangan pada tanggal 24 Juli 2011.

Tabel 2. Hasil Pengolahan Klorofil Tahun 2009 -2011

Nilai Klorofil (mg/m3)

\begin{tabular}{|c|c|c|c|c|c|}
\hline No & Citra & Tahun & $\begin{array}{c}\text { Lokasi } \\
\text { Penelitian } \\
\text { Ke-1 }\end{array}$ & $\begin{array}{c}\text { Lokasi } \\
\text { Penelitian } \\
\text { Ke-2 }\end{array}$ & $\begin{array}{c}\text { Lokasi } \\
\text { Penelitian } \\
\text { Ke-3 }\end{array}$ \\
\hline 1 & & 2009 & 0,001539 & 0,001539 & 0,001750 \\
\hline 2 & $\begin{array}{c}\text { Terra } \\
\text { MODIS }\end{array}$ & 2010 & 0,008139 & 0,009483 & $\mathrm{~N} / \mathrm{A}$ \\
\hline 3 & & 2011 & 0,047073 & 0,0046922 & 0,0046922 \\
\hline 4 & & 2009 & 0,008837 & $\mathrm{~N} / \mathrm{A}$ & $\mathrm{N} / \mathrm{A}$ \\
\hline 5 & $\begin{array}{l}\text { Aqua } \\
\text { MODIS }\end{array}$ & 2010 & 1,841472 & 1,836017 & 1,836017 \\
\hline 6 & & 2011 & 0,016994 & 0,016994 & 0,016782 \\
\hline
\end{tabular}

Keterangan

N/A : Not Available, data klorofil tidak diketahui karena lokasi penelitian tertutup awan

\section{Uji Validasi}

Uji validasi dilakukan pada citra dan data lapangan tanggal 24 Juli 2011.Pada uji validasi ini dilakukan penghitungan korelasi dengan membandingkan data hasil klorofil groundtruth dengan klorofil hasil pengolahan citra. Hal ini di gunakan untuk melihat sejauh mana kedekatan atau kebaikan data citra yang digunakan. Pada uji validasi ini dihasilkan nilai koefisien determinasi sebesar $77,57 \%$ yang divisualisasikan pada grafik Gambar 3.dibawah ini.

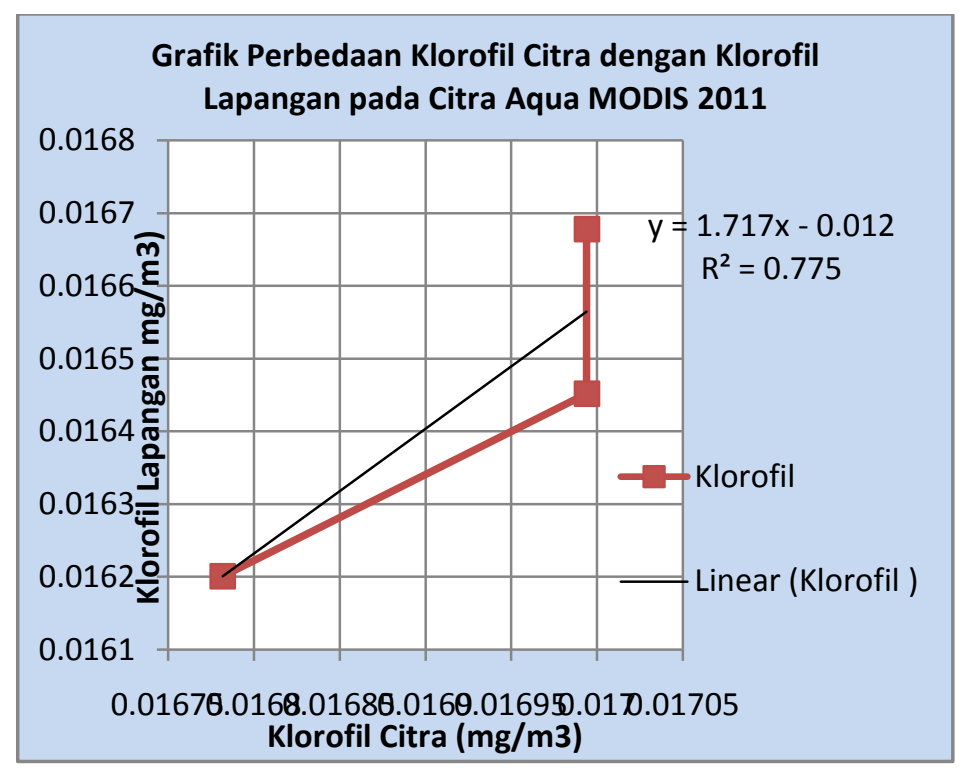

Gambar 3. Grafik Perbedaan Klorofil Citra dengan Lapangan pada Citra Aqua MODIS 2011

Model matematis yang dapat menjelaskan perbandingan kedua data ini adalah

$$
Y=-1,717 x-0,0126
$$

\section{Dimana : $Y=$ Klorofil Lapangan $\mathrm{X}=$ Klorofil Citra}

Dari nilai $\mathrm{R}^{2}$ ini menjelaskan bahwa variabilitas dari data citra untuk dapat menggambarkan data di lapangan adalah sebesar $77,57 \%$. Nilai $R^{2}$ yang mendekati satu atau $100 \%$ menunjukkan hubungan yang positif, sebaliknya jika $R^{2}$ mendekati nol, maka memiliki hubungan tidak baik. Dari hubungan ini dijelaskan bahwa sebagian besar klorofil di lapangan dapat dijelaskan oleh citra, sedangkan sisanya sebesar $22,43 \%$ adalah faktor-faktor lain yang tidak diamati oleh citra.

Pada Terra MODIS tahun 2011, dihasilkan nilai koefisien determinasi sebesar $72,34 \%$ yang divisualisasikan pada grafik Gambar 4 dibawah ini. 


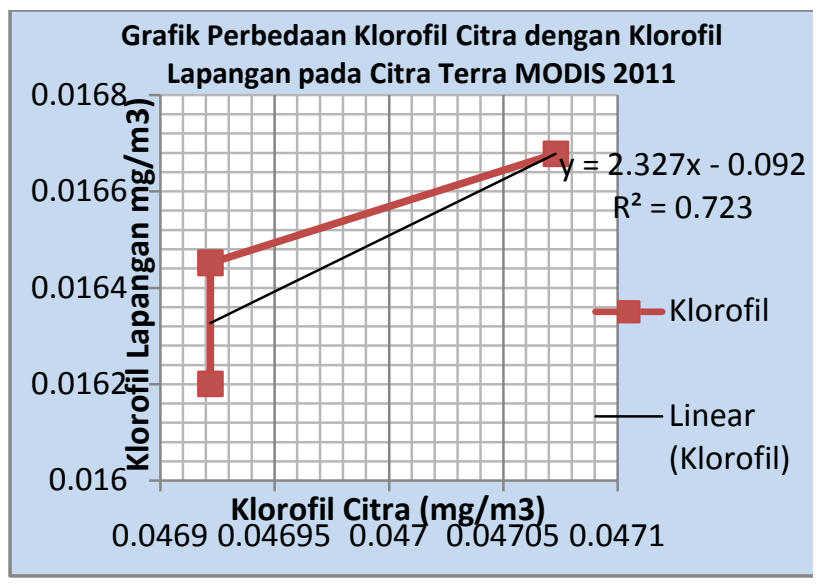

Gambar 4. Grafik Perbedaan Klorofil Citra dnegan Lapangan pada Citra Terra MODIS 2011

Model matematis yang dapat menjelaskan perbandingan kedua data ini adalah

$$
Y=2,3278 x-0,0929
$$

$$
\text { Dimana } \begin{aligned}
: Y & =\text { Klorofil_Lapangan } \\
X & =\text { Klorofil Citra }
\end{aligned}
$$

Dari nilai $R^{2}$ ini menjelaskan bahwa variabilitas dari data citra untuk dapat menggambarkan data di lapangan adalah sebesar $72,34 \%$. Nilai $R^{2}$ yang mendekati satu atau $100 \%$ menunjukkan hubungan yang positif, sebaliknya jika $R^{2}$ mendekati nol, maka memiliki hubungan tidak baik. Dari hubungan ini dijelaskan bahwa sebagian besar klorofil di lapangan dapat dijelaskan oleh citra, sedangkan sisanya sebesar $27,66 \%$ adalah faktor-faktor lain yang tidak diamati oleh citra.

\section{Analisa Data Lapangan dengan Data Citra}

Dari gambar 4 dan 5 dapat dianalisa bahwa adanya perbedaan nilai klorofil dari data lapangan dengan data citra yang ada, yaitu: pada Citra Aqua MODIS, didapatkan nilai koefisien determinasi sebesar $77,57 \%$ sedangkan pada citra Terra MODIS sebesar 72,34, ini dapat diambil kesimpulan bahwa citra Aqua MODIS yang memiliki hasil lebih baik, yang dapat digunakan untuk mengetahui nilai klorofil yang ada di lapangan.
Meskipun nilai koefisien determinasi dari kedua citra masuk dalam toleransi yang ditetapkan, namun hasil yang lebih baik ada pada citra Aqua MODIS yang mempunyai nilai koefisien determinasi lebih tinggi.

Pada koreksi geometrik, didapatkan nilai $\mathrm{RMS}_{\text {error }}$ rata-rata sebesar < 0,6 baik dari citra Terra maupun Aqua MODIS., sehingga nilai $\mathrm{RMS}_{\text {error }}$ rata-rata kurang dari 1 pixel dianggap memenuhi toleransi yang diberikan (Purwadhi, 2001). Nilai strength of figure dari titik kontrol registrasi citra untuk setiap citra yang digunakan adalah 0,0012 Dalam hal ini semakin kecil bilangan faktor kekuatan jaringan tersebut di atas, maka akan semakin baik konfigurasi jaringan yang bersangkutan, dan sebaliknya.

\section{Analisa Sebaran Klorofil}

Berdasarkan hasil pengolahan citra, didapatkan nilai klorofil yang sebesar $0,01-1,8 \mathrm{mg} / \mathrm{m} 3$. Hal ini disebabkan karena adanya faktor tertentu yang mengakibatkan nilai klorofil rendah.

Persebaran klorofil disebabkan karena banyak faktor. Antara lain:

1. Perairan oseanis di daerah tropis umumnya memiliki konsentrasi klorofil yang rendah.

2. Klorofil yang berada di daerah sekitar pantai cenderung lebih tinggi daripada di tengah lautan.

3. Adanya upwelling

4. Kekeruhan tinggi menghambat penetrasi cahaya ke dalam air

\section{KESIMPULAN dan SARAN}

\section{Kesimpulan}

Dari penelitian tentang studi persebaran konsentrasi klorofil menggunakan citra Terra dan Aqua MODIS, dapat diambil kesimpulan:

1. Nilai RMSerror rata-rata < 0.6. Untuk nilai RMSerror citra Terra MODIS tahun 2009 sebesar 0,431, tahun 2010 sebesar 0,735 dan tahun 2011 sebesar 0,635. Kemudian pada citra Aqua MODIS nilai RMSerror pada tahun 2009 sebesar 0,468, tahun 2010 sebesar 0,693 dan tahun 2011 sebesar 0,622. Kedua citra mempunyai nilai SOF 0,0012 . 
2. Berdasarkan hasil validasi dari perbandingan data survei dengan data klorofil citra tanggal 24 Juli 2011, dapat dianalisa bahwa adanya perbedaan nilai klorofil dari data lapangan dengan data citra yang ada, yaitu: pada Citra Aqua MODIS, didapatkan nilai koefisien determinasi sebesar $77,57 \%$ sedangkan pada citra Terra MODIS sebesar $72,34 \%$, ini dapat diambil kesimpulan bahwa citra Aqua MODIS yang memiliki hasil lebih baik dan data klorofil yang digunakan telah merepresentasikan kondisi suhu yang sesungguhnya, yang dapat digunakan untuk mengetahui nilai klorofil yang ada di lapangan. Meskipun nilai koefisien determinasi dari kedua citra masuk dalam toleransi yang ditetapkan, namun hasil yang lebih baik ada pada citra Aqua MODIS adalah yang mempunyai nilai koefisie determinasi lebih tinggi.

3. Nilai klorofil rata - rata antara 0,001-1,8 $\mathrm{mg} / \mathrm{m} 3$. Untuk nilai klorofil citra Terra MODIS tahun 2009 sebesar $0,00160 \mathrm{mg} / \mathrm{m3}$, tahun 2010 sebesar 0,00881 mg/m3 dan tahun 2011 sebesar 0,14092 mg/m3. Kemudian pada citra Aqua MODIS nilai klorofil tahun 2009 sebesar $0,0088 \mathrm{mg} / \mathrm{m} 3$, tahun 2010 sebesar 1,8378 $\mathrm{mg} / \mathrm{m} 3$ dan tahun 2011 sebesar 0,01692 $\mathrm{mg} / \mathrm{m} 3$.

4. Persebaran klorofil disebabkan karena banyak faktor. Antara lain:

a. Perairan oseanis di daerah tropis umumnya memiliki konsentrasi klorofil yang rendah.

b. Klorofil yang berada di daerah sekitar pantai cenderung lebih tinggi daripada di tengah lautan.

c. Adanya upwelling

d. Kekeruhan tinggi menghambat penetrasi cahaya ke dalam air

\section{Saran}

Kendala dalam penelitian klorofil menggunakan data citra Terra dan Aqua MODIS level 1B adalah citra yang diperoleh berupa data mentah yang harus diproses menggunakan algoritma untuk memisahkan data - data yang terdapat pada citra Terra maupun Aqua MODIS. Oleh karena alasan tersebut untuk penelitian selanjutnya yang terkait dengan klorofil sebaiknya menggunakan data citra dengan level yang lebih tinggi, seperti level 2 dan level 3. Sebab level 2 merupakan data citra Terra dan Aqua MODIS yang telah terdapat proses algoritmanya dan umumnya ahli oseonografi menggunakan data ini untuk penelitian yang akan dilakukan. Sedangkan level 3, data citra yang telah terkoreksi radiometrik dan geometrik, serta algortitma pada level 3 telah diterapkan secara otomatis.

Perlu adanya penelitian lanjut tentang studi mengenai klorofil dengan menggunakan metodemetode yang berbeda, bila perlu membuat suatu metode yang paling cocok diterapkan pada perairan Selat Madura.

\section{DAFTAR PUSTAKA}

Afdal. 2004. "Sebaran Klorofil-a Kaitannya Dengan Kondisi Hidrologi Di Selat Makassar". Jurnal Oseanografi dan Limnologi di Indonesia 2004 Bidang Dinamika Laut Pusat Penelitian Oseanografi LIPI No. 36: 69-82

Arief, M. 2006. "Analisis Kesesuaian Perairan Tambak Di Kabupaten Demak Ditinjau Dari Nilai Klorofil-A, Suhu Permukaan Perairan, dan Muatan Padatan Tersuspensi Menggunakan Data Citra Satelit Landsat ETM 7+".Jurnal Penginderaan Jauh LAPAN Vol 39 Juni 2006: 108-US

Arifin, I.S. 2010. Studi Perubahan Muatan Padatan Tersuspensi (TSM) di Selat Madura Akibat Pembuangan Lumpur Lapindo. Surabaya : Tugas Akhir Program Studi Geomatika ITS

Effendi. H. 2003. Telaah Kualitas Air bagi Pengelolaan Sumberdaya dan Lingkungan Perairan. Penerbit Kanisius. Yogyakarta.

Lillesand, T.M., Kiefer, R.W., and Chipman J.W. 1994. Remote Sensing and Image Interpretation. Fifth Edition. New york : John Wiley \& Sons

Martin, S. 2004. An Introduction to Ocean Remote Sensing. United Kingdom : University of Cambridge

Pahlevi, A M. 2009. Analisa Sedimentasi di Muara kali Porong Akibat Pembuangan Lumpur Lapindo Menggunakan Data Citra Satelit ASTER. Surabaya : Tugas Akhir Program Studi Geomatika ITS

Purwadhi, S.H. 2001. Interpretasi Citra Digital. Jakarta: Grasindo

Santoso, B. 2010. Prediksi Potensi Daerah Ikan MenggunakanCitra Aqua Modis Dan Pendistribusian Hasil Dengan Menggunakan Web (Studi Kasus : Perairan Selatan Jawa Timur - Bali). Surabaya : Program Studi Geomatika ITS.

Soegianto, A. 2004. Metoda Pendugaan Pencemaran dengan Indikator Biologis. Airlangga University Press. Surabaya 
Susilo, S.B. 2000. Penginderaan Jauh Terapan. Fakultas Perikanan dan Ilmu Kelautan. Institut Pertanian Bogor

Syafi'i, M. 2006. Sebaran Konsentrasi Klorofil-a dan Suhu Permukaan Laut Menggunakan Citra Satelit Terra MODIS di Perairan Natunal : Tugas Akhir
Program Studi Ilmu dan Teknologi Kelautan IPB.Bogor

Wahyu, A. 2005.Pemetaan Persebaran Korofil Wilayah Perairan Selat Bali Menggunakan Teknologi Penginderaan Jauh : Tugas Akhir Program Studi Teknik Geomatika ITS. Surabaya 